\title{
AFLATOXIN M1 LEVELS IN MILK AND SOME DAIRY PRODUCTS IN ALEXANDRIA CITY
}

\author{
AHMED S. AIAD ${ }^{*}$ and ABO EL-MAKAREM H. S. ${ }^{* *}$ \\ * Animal Health Research Institute (Alexandria branch), Egypt \\ ${ }^{* *}$ Dept. Food Hygiene, Fac. Vet. Med., Alex. Univ., Egypt \\ Email: ahmedaiad71@yahoo.com
}

\begin{tabular}{|c|c|}
\hline & ABSTRACT \\
\hline Received at: $29 / 9 / 2013$ & $\begin{array}{l}\text { Aflatoxin M1 (AFM1) is the major mycotoxin frequently found in milk and dairy } \\
\text { products. AFM1 is a carcinogenic metabolite often found in dairy products. The } \\
\text { present study was carried out to evaluate the occurrence of AFM1 in milk and some } \\
\text { dairy products in Alexandria city. A total number of } 150 \text { samples, } 30 \text { each of Raw } \\
\text { milk, Kareish cheese, Damietta cheese, Ras cheese and Yoghurt were randomly } \\
\text { purchased from supermarkets in Alexandria city from January to August } 2013 \text { for } \\
\text { determination of AFM1 by using direct competitive enzyme-linked immunosorbent } \\
\text { assay (ELISA). Results showed that the mean concentration values of AFM1 was } \\
\text { detected in } 40 \% \text { of the analyzed milk samples with levels ranging from } 8.30 \text { to } 85.00 \\
\text { ng/kg, AFM1 was detected in } 46,53 \text { and } 56 \% \text { of examined Kareish cheese, Damietta } \\
\text { cheese and Ras cheese samples with levels ranging from } 6.20 \text { to } 70.26,16.50 \text { to } 133.2 \\
\text { and } 7.40 \text { to } 111.50 \text { ng/kg, respectively. While, results showed that AFM1 was } \\
\text { detected in } 26 \% \text { of analyzed yoghurt samples with level ranging from } 11.40 \text { to } 98.80 \\
\text { ng/kg. All positive samples of raw milk, cheeses and yoghurt are exceeding Egyptian } \\
\text { regulations (1990), while all of them are within the US regulations (Stoloff et al., } \\
1991) \text {. While } 71,75 \text {, } 88 \% \text {, of positive samples in kareish cheese, Damietta cheese and } \\
\text { Ras cheese samples, respectively were exceeding the European Commission } \\
\text { Regulation (Codex Alimentarius Commission, } 2001 \text { ). Also } 58 \% \text { of positive raw milk } \\
\text { samples and } 63 \% \text { of positive examined yoghurt samples were exceeding the } \\
\text { European Commission regulation. It was concluded that widespread occurrence of } \\
\text { AFM1 in raw milk and some dairy products samples were considered to be possible } \\
\text { hazards for public health especially children. }\end{array}$ \\
\hline
\end{tabular}

Key words: Aflatoxins M1, raw milk, dairy products, ELISA.

\section{INTRODUCTION}

Milk and dairy products are fundamental components in the human diet, and may be the principle way for entrance of aflatoxins into the human body (Galvano et al., 1998). The consumption of contaminated milk and dairy products especially cheese is an important risk factor for consumers in particular for infants and young children, (Colak, 2007).

Aflatoxins are toxic metabolites, generally produced by Aspergillus flavus, A. parasiticus and A. nomius (Creppy, 2002). AFM1 is a hydroxylated metabolite of aflatoxin B1 and can be detected in milk and dairy products from dairy cattle that have ingested feed contaminated with aflatoxin B1. (IARC, 1993). Both AFM1 and AFB1 can cause DNA damage, gene mutation, chromosomal anomalies and cell transformation in mammalian cells in vitro (Govaris, et al., 2002). The occurrence of AFM1 in commercially available milk and dairy products is a matter of interest for public health due to continuous and prolonged exposure to a carcinogenic substance. Aflatoxin $\mathrm{M}_{1}$ presence in milk is considered as a potential risk for human health because of its carcinogenicity potential and thus a need of regular monitoring in milk and dairy products (Prado et al., 2000). The presence of AFM1 in cheese is thus considered undesirable due to toxic and carcinogenic properties (Amer and Ibrahim, 2010).

In addition, several authors have demonstrated that AFM1 is bound to milk proteins (Prandini et al., 2009), mainly casein, and therefore the toxin is more concentrated in cheese than in the milk used to produce it.

Kareish cheese is one of the most popular fresh skim milk soft cheeses in Egypt. The increasing demand by Egyptian consumers is mainly attributed to its high protein content and low price (Osman et al., 2012). AFM1 in Kareish cheese samples during storage might be attributed to the affinity of AFM1 for caseins which may cause concentration effect during milk process as well as the rather stable $\mathrm{pH}$ values (Capei and Neri, 2007).

AFM1 resistant to heat treatment and mild acidic conditions used in the production of cheese or other dairy products (such as, yoghurt) has been accounted for the contamination of such products (Colak, 2007 and Oruc et al., 2007). 
Regulatory limits throughout the world are influenced by economic considerations and may vary from one country to another (Stoloff et al., 1991). The European Community and Codex Alimentarius have prescribed that the maximum limit of AFM1 in liquid milk and milk products is $50 \mathrm{ng} / \mathrm{kg}$ (European Commission Regulation, 2001). According to USA regulations, the level of AFM1 in milk should not be higher than $500 \mathrm{ng} / \mathrm{kg}$ (Stoloff et al., 1991). In Egypt, the Ministry of Health established that fluid milk and dairy products should be free from AFM1 (Egyptian Regulations, 1990).

Although the mycological quality of raw milk and cheese In Egypt has been studied extensively, there are rare available data on the content of AFM1 in raw milk and dairy products. The occurrence of AFM1 in commercially available milk and dairy products is a matter of interest for public health due to continuous and prolonged exposure to a carcinogenic substance. As the ingestion of contaminated food is the primary route of potential human exposure to aflatoxins, the aim of this research is to determine the concentrations of AFM1 in raw milk and some dairy products retailed in Alexandria city, to compare these levels with maximum AFM1 limits adopted by Egyptian, European and USA regulations and to determine the potential risk posed to human health by the Consumption of these products.

\section{MATERIALS and METHODS}

\section{Samples:}

A total number of 150 samples 30 from each of raw milk, Kareish cheese, Damietta cheese, Ras cheese and yoghurt were randomly obtained from super markets in Alexandria city. Samples were transported to the laboratory in an insulated container at about $4^{\circ} \mathrm{C}$ and analyzed for AFM1.

\section{Sample preparation:}

All milk and dairy products samples were prepared using the method outlined in the ELISA kits and according to official method specified in ELISASystem Aflatoxin M1. (RIDAScreen aflatoxin M1 (Cat. No. R1101).

\section{- Raw milk samples}

Twenty milliliters of liquid raw milk was centrifuged at $3500 \mathrm{rpm} / 10$ minutes. The fatty layer was removed and $100 \mu \mathrm{l}$ of the defatted milk was applied directly in the ELISA kit for AFM1 determination.

\section{- Cheese samples}

Cheese samples were prepared according to the method outlined in the ELISA kit. Two grams of a representative cheese samples were homogenized then added to $40 \mathrm{ml}$ of dichloromethane. The mixture was extracted by shaking for $15 \mathrm{~min}$., the suspensions were filtered and $10 \mathrm{ml}$ of the filtrate were evaporated at $60^{\circ} \mathrm{C}$ under weak $\mathrm{N}_{2}$ stream. The oily residue was re-dissolved in a mixture of $0.5 \mathrm{ml}$ methanol, $0.5 \mathrm{ml}$ phosphate buffer saline and $1 \mathrm{ml}$ of heptane. The mixture was centrifuged at $2700 \mathrm{rpm} / 15 \mathrm{~min}$. The upper layer of heptane was removed and $100 \mu$ l of the aliquot were diluted with $400 \mu \mathrm{l}$ of kit buffer. $100 \mu \mathrm{l}$ of the diluted samples were applied in the kit.

\section{- Yoghurt samples}

Ten grams of yoghourt samples were added to $100 \mathrm{ml}$ of warm $\left(20-25^{\circ} \mathrm{C}\right)$ deionized water and shacked for $10 \mathrm{~min}$ in speed of $250 \mathrm{~min}-1$. Subsequently, these samples were centrifuged at $3500 \mathrm{rpm} / 10 \mathrm{~min}$ at $4^{\circ} \mathrm{C}$. The upper creamy layers were completely discarded and the lower phases were further diluted 20 times $(\mathrm{v} / \mathrm{v})$ with deionized water and then were used for the quantitative test according to the method outlined in the ELISA kit.

\section{ELISA test procedure: Analysis of AFM1 in samples by competitive ELISA}

The quantitative analysis of AFM1 in milk and dairy products samples was performed by competitive ELISA (RIDASCREEN AFM1, R-Biopharm) procedure as described by R-biopharm GmbH (1999). Which is a competitive enzyme immunoassay based on antigen-antibody reaction. The wells in the microtiter strips were coated with specific antibodies to AFM1. $100 \mu \mathrm{l}$ of sample solution $+100 \mu \mathrm{l}$ of standard $10 \mathrm{ng} / \mathrm{kg}$ (standard addition method was used because of detection limit $5 \mathrm{ng} / \mathrm{kg}$ ) were added to the wells to occupy the binding sites proportionately, then mixed gently and incubated for $60 \mathrm{~min}$ at room temperature in the dark. Then the liquid samples were poured out of the wells and the wells were filled with $250 \mu \mathrm{l}$ distilled water and poured out the liquid. Further steps were done according to the kit instruction and ultimately each well was washed four times by washing buffer. After almost one hour, light absorption was read at $450 \mathrm{~nm}$ by ELIZA reader. The standard curve was used for determination related to the kit, milk and dairy products samples by competitive ELISA.

\section{RESULTS}

As it is shown in Table 1 the mean concentration values of AFM1 in Damietta cheese, Ras cheese samples were higher than that in raw milk samples, while the mean concentration values of AFM1 in Kareish cheese samples were lower than that of raw milk samples, Yoghurt samples were the least contaminated type of examined dairy products.

Table 2: shows that all positive samples of raw milk and cheeses are exceeding the Egyptian regulations, while all of them are within the US regulations (500 $\mathrm{ng} / \mathrm{l}$ or $\mathrm{Kg}$ ). $71,75,88,63 \%$ of positive samples in Kareish cheese, Damietta cheese, Ras cheese and Yoghurt samples were exceeding the European Commission regulation ( $50 \mathrm{ng} / \mathrm{l}$ or $\mathrm{Kg}$ ), while $58 \%$ of examined raw milk samples were exceeding European Commission regulation. 
$\underline{\text { Assiut Vet Med. J. Vol } 59 \text { No. } 139 \text { October } 2013}$

Table 1: Concentrations of AFM1 in raw milk and some dairy products Samples.

\begin{tabular}{ccccccc}
\hline \multirow{2}{*}{ Sample category } & $\begin{array}{c}\text { Samples } \\
\text { analyzed }\end{array}$ & \multicolumn{2}{c}{ Positive samples } & \multicolumn{2}{c}{ AFM1Concentration (ng/l or Kg) } \\
\cline { 3 - 7 } & & No & $\mathbf{( \% )}$ & Minimum & Maximum & Mean \pm SD \\
\hline Raw milk & 30 & 12 & 40 & 8.30 & 85.00 & $32.56 \pm 5.98$ \\
\hline Kareish cheese & 30 & 14 & 46 & 6.20 & 70.26 & $28.66 \pm 4.66$ \\
\hline Damietta cheese & 30 & 16 & 53 & 16.50 & 133.2 & $53.059 \pm 8.013$ \\
\hline Ras cheese & 30 & 17 & 56 & 7.40 & 111.50 & $56.048 \pm 6.29$ \\
\hline Yoghurt & 30 & 8 & 26 & 11.40 & 98.80 & $28.41 \pm 4.78$ \\
\hline
\end{tabular}

Table 2: Levels of AFM1 (ng/l or $\mathrm{Kg}$ ) in samples exceeding limits established by the Egyptian regulations and EC/Codex.

\begin{tabular}{|c|c|c|c|c|c|c|}
\hline \multirow[t]{2}{*}{ Sample category } & \multicolumn{2}{|c|}{ Positive samples } & \multicolumn{2}{|c|}{$\begin{array}{l}\text { Exceeding Egyptian Regulation } \\
\text { (free from AFM1) }\end{array}$} & \multicolumn{2}{|c|}{$\begin{array}{l}\text { Exceeding EC } \\
\text { regulations } \\
(50 \mathrm{ng} / \mathrm{Kg})\end{array}$} \\
\hline & No. & $(\%)$ & No & $(\%)$ & No. & $(\%)$ \\
\hline Raw milk & 12 & 40 & 12 & 100 & 7 & 58 \\
\hline Kareish cheese & 14 & 46 & 14 & 100 & 10 & 71 \\
\hline Damietta cheese & 16 & 53 & 16 & 100 & 12 & 75 \\
\hline Ras cheese & 17 & 56 & 17 & 100 & 15 & 88 \\
\hline Yoghurt & 8 & 26 & 8 & 100 & 5 & 63 \\
\hline
\end{tabular}

\section{DISCUSSION}

Food safety and foodborne diseases constitute a growing public health problem (WHO, 2009). Thus, great attention must be given to food control especially mycotoxins investigation in food due to their deleterious effect on human health. Mycotoxins are metabolites of fungi capable of having acute toxic, carcinogenic, mutagenic, teratogenic, immunotoxic, and oestrogenic effects in man and animals (Van Egmond et al., 2007). Aflatoxin M1 (AFM1) particularly is the principal hydroxylated metabolite of aflatoxin B1 excreted in milk, and subsequently it can be found in a large variety of dairy products such as cheese thus posing a potential risk to human health when consuming these products (Barug et al., 2004).

The quality of milk products has a strong influence on the health of people in various age brackets. AFM1 is known to be hepatotoxic and carcinogenic. The World Health Organization changed its classification from group 2 to group 1 (Creppy, 2002). In this study the mean concentration values of AFM1 was detected in $40 \%$ of the analyzed milk samples with levels ranging from 8.30 to $85.00 \mathrm{ng} / \mathrm{kg}$, AFM1 was detected in 46, 53 and $56 \%$ of the examined Kareish cheese, Damietta cheese, Ras cheese samples with levels ranging from 6.20 to $70.26 \mathrm{ng} / \mathrm{kg}, 16.50$ to $133.2 \mathrm{ng} / \mathrm{kg}$ and 7.40 to $111.50 \mathrm{ng} / \mathrm{kg}$, respectively. 
Furthermore, high incidence similar to our results was reported in North Africa. Forty-nine samples of raw cow's milk were collected directly from 20 dairy factories in the north-west of Libya and analyzed for the presence of AFM1. Thirty-five milk samples (71.4\%) showed AFM1 levels between 0.03 and 3.13 $\mathrm{ng} / \mathrm{ml}$ (Elgerbi, 2004).

The wide range of AFM1 in hard cheese can be ascribed to different factors such as extraction technique, methodology, type and degree of milk contamination, differences in milk quality, expression of the results, the presence of a small portion of curd in whey which could influence AFM1 concentration, and the cheese manufacturing process (Blanco et al., 1988). Aflatoxins may be found in cheese originating from three possible sources: a) presence of AFM1 in milk with which cheese are manufactured, as a consequence of food contaminated with AFB1 eaten by dairy cattle; b) synthesis of $\mathrm{AFB}_{1}, \mathrm{~B}_{2}, \mathrm{G}_{1}$, and $\mathrm{G}_{2}$ by fungi which grow on cheese such as Aspergillus spp. and c) the use of dried milk with AFM1, to enrich the milk employed in cheese production. When cheese is manufactured from AFM1-contaminated milk, the toxin can be carried over into both whey and cheese (Colak, 2007).

Results showed that AFM1 was detected in $26 \%$ in analyzed yoghurt samples with level ranging from 11.40 to $98.8 \mathrm{ng} / \mathrm{kg}$. All positive samples of raw milk, cheeses and yoghurt are exceeding Egyptian regulations which stated that milk and dairy products should be free from AFM1, while all of them are within the US regulations $(500 \mathrm{ng} / \mathrm{Kg})$. While 71, 75, $88 \%$, of positive samples in Kareish cheese, Damietta cheese and Ras cheese samples, respectively were exceeding the European Commission regulations $(50 \mathrm{ng} / \mathrm{Kg})$. Also $58 \%$ of positive examined raw milk samples and $63 \%$ of positive examined yoghurt samples were exceeding the European Commission regulation.

Milk and other dairy products are always at risk of being contaminated with aflatoxin M1. Mycotoxin compounds are extremely stable and also dangerous in minute quantities. A few parts per billion are of concern. Once formed, they cannot be removed from the commodity. Milk, as a liquid, is a highly variable product that rapidly loses its quality and spoils if not to be treated. Since milk may be processed in numerous ways, the effects of storage and processing on stability and distribution of AFM1 are of great concern. Many researchers from different countries have carried out studies about the incidence of AFM1 in milk; many authors showed that seasonal effect influences concentration of aflatoxin M1. They reported higher concentration of AFM1 in cold seasons as compared to hot seasons, the reason being in winters mostly milking animals are fed with compound feeds and thus concentration of AFB1 increases which in turn enhances AFM1 concentration in milk (Azizollahi et al., 2012).

Dairy products play a significant role in human diet since they are rich sources of bioavailable calcium and proteins. However, many of the previous studies has indicated the presence of AFM1 at high concentrations in dairy products (Tekinsen and Tekinsen 2005). The low level of AFM1 in examined yoghurt samples could be attributed to factors such as low $\mathrm{pH}$, formation of organic acids or even to the presence of lactic acid bacteria. The low $\mathrm{pH}$ could alter the structure of milk proteins and leading to formation of yoghurt coagulum that it may affect the association of AFM1 with this protein causing adsorption of the toxin. Also enzymatic, microbial and particularly acid coagulation can cause degradation of AFM1 in milk (El Deeb et al., 1992)

Milk and dairy products provide major nutrition's for human because many people especially children, frequently include them in their diets (Baskaya, 2006).AFM1 is resistant to thermal inactivation, pasteurization. Autoclaving and other varieties of food processing procedures (Park, 2002). It is essential to keep feeds free from contamination by AFB1 which is the mother molecule of AFM1. The concentration of AFBlin animal feed can be reduced by good manufacturing practice and good storage practices. If preventive measure fails, AFB1 can be reduced in feed that has low concentrations or by chemical, physical or biological treatment (Signorini, 2011). It is important to reduce the occurrence of AFB1 in feedstuff and take prophylactic measures to prevent factors enhancing toxin production. These factors include environmental temperature, humidity, and moisture content of the feed. These results suggest that it is important to prevent toxin production in these products from the production stage to consumption as well as creating effective detoxification processes probably lactic acid bacteria used in yoghurt offer means of decontaminating AFM1 from milk (El-Nezami et al., 1998).

\section{CONCLUSION and RECOMMENDATION}

Frequent analytical surveillance by food control agencies is highly recommended to control the incidence of mycotoxin contamination in Egypt especially in dairy products. Raw milk has to be controlled continuously for presence of AFM1 contamination. It is also extremely important to maintain low levels of AFB1 in the feeds of dairy animals. Implementing a food control system, such as the HACCP system, in the food industries is suggested as an efficient means for limiting aflatoxin contamination in the Egypt's food supply. 


\section{REFERENCES}

Amer, A.A. and Ibrahim, E.M.A. (2010): Determination of aflatoxin M1 in raw milk and traditional cheeses retailed in Egyptian markets. J. Toxicol. Environ. Health Sci., 2(4): 50-53.

Azizollahi, A.M.; Issazadeh, R.; Kazemi Darsanaki, M.; Laleh, R. and, Amini, A. (2012): Determination of Aflatoxin M1 Levels in White Cheese Samples by ELISA in Gilan Province, Iran. Global Veterinaria., 8 (7): 707 710.

Barug, D.; Van Egmond, H.; Lopez-Garcia, R.; Van Osenbruggen, and Visconti, A. (2004): Meeting the mycotoxins menace. Wageningen Academic Publishers, the Netherlands, ISBN 978-90-76998-28-2, 305p.

Baskaya, R.; Aydin, A.; Yildiz, A. and Bostan, K. (2006): Aflatoxin M1 levels of some cheese varieties in Turkey. Medycyna Wet. 62: 778780.

Blanco, J.L.; Domingues, L.; Gomez-lucia, E.; Garayzabal, J.F.F.; Goyache, J. and Suarez, $G$. (1988): Behavior of aflatoxin during the manufacture, ripening and storage of Manchego-type cheese. J. Food Sci., 53: 13731376.

Capei, C. and Neri, P. (2007): The behavior of aflatoxin M1 in some dairy products, Bulletin of the Environmental Contamination and Toxicology, 14 (3), 313-319.

Codex Alimentarius Commission (2001): Comments submitted on the draft maximum level for Aflatoxin M1 in milk. Codex committee on food additives and contaminants 3rd session. The Netherlands: Hague.

Colak, H. (2007): Determination of aflatoxin M1 levels in Turkish white and kashar cheeses produced from experimentally contaminated raw milk. J. Food and Drug Anal. 15(2): 163168.

Creppy, E.E. (2002): Update of survey, regulation and toxic effects of mycotoxins in Europe. Toxicol. Lett., 127: 19-28.

Egyptian regulations (1990): Maximum Limits for Mycotoxin in Foods. Part L Aflatoxins E.S. 1875-1990. Egyptian Organization for Standardization and Quality Control.

El Deeb, S.A.; Zaki, N.; Shoukry, Y.M.R. and Kheadr, E.E. (1992): Effect of some technological processes on stability and distribution of aflatoxin M1 in milk. Egyptian Journal of Food Science 20: 29-42.

Elgerbi, A.M.; Aidoo, K.E.; Candlish, A.A.G. and Tester, R.F. (2004): Occurrence of aflatoxin M1 in randomly selected North African milk and cheese samples. Food Additives \& Contaminants: Part A, 21(6): 592-597.
El-Nezami, H.; Kankaanpaa, P.; Salminen, S. and Ahokas, J. (1998): Ability of dairy strains of lactic acid bacteria to bind a common food carcinogen, aflatoxin B1. Food Chem. Toxicol. 36 (4): 321-6.

European Commission Regulation (2001): No.466/2001/EC of 8 March 2001, setting maximum levels for certain contaminants in food stuffs. Official Journal of the European Commission, L077; 1-13.

Galvano, F.; Galofaro, V.; DeAngelis, A.; Galvano, M.; Bognanno, M. and Galvano, G. (1998): Survey of the occurrence of aflatoxin M1 in dairy products marketed in Italy. J. Food Protection, 61: 738-741.

Govaris, A.; Roussi, V.; Koudis P.A. and Botsoglou, N.A. (2002): Distribution and stability of aflatoxin M1 during production and storage of yoghurt. Food Additives and Contaminants 11: 1043-1050

IARC, International Agency for Research on Cancer (1993): Some naturally occurring substances: food items and constituents heterocyclic aromatic amines and mycotoxins France: Lyon. 56: 245-395

Oruc, H.H.; Cibik, R.; Yilrnaz, E. and Gunes, E. (2007): Fate of aflatoxin M1 in Kashar cheese. Journal of Food Safety, 27, 82-90.

Osman, O.; Ozturk, I.; Bayram, O.; Kesmen, Z. and Yilmaz, M.T. (2012): Determination of aflatoxin M1 in Kareish cheese, Egyptian J. Dairy Sci., 75 (2), 2012, 637-640.

Park, D.L. (2002): Effect of processing on aflatoxin. Adv. Exp. Med. Biol., 504: 173-179.

Prado, G.; Oliviera, M.S.; Pereira, M.L.; Abrantes, F.M.; Santos, L.G. and Veloso, T. (2000): Aflatoxin M1 in samples of Mina's cheese commercialized in the city of Belo HorizonteMinas Gerrais/Brazil. Ciencia e Technologia de Alimentos, 20(3): 398-400.

Prandini, A.; Tansini, G.; Sigolo, S.; Filippi, L.; Laporta, M. and Piva, G. (2009): On the occurrence of aflatoxin M1 in milk and dairy products. Food and Chemical Toxicology, 47, 984-991.

R-Biopharm GmbH (1999): "Enzyme immunoassay for the quantitative analysis of aflatoxins," Ridascreen Aflatoxin M1 Art. R-1101, RBiopharm GmbH, Darmstadt, Germany.

Signorini, M.; Gaggiotti, M.; Molineri, A.; Chiericatti, C.; Zapata de Basílico, M. and Basílico, J. et al. (2011): Exposure Assessment of Mycotoxins in Cow's Milk in Argentina. Food and Chemical Toxicology.

Stoloff, L.; Van Egmond, H.P. and Park, D.L. (1991): Rationales for establishment of limits and regulations for mycotoxins. Food Additives Contaminants, (Abstract). 8: 213-222.

Tekinsen, K.K. and Tekinsen, O.C. (2005): Aflatoxin M1 in white pickle and Van otlu (herb) cheeses 
consumed in south eastern Turkey. Food Control, 16: 565-568.

Van Egmond, H.P.; Schothorst, R.C. and Jonker, M.A. (2007): Regulations relating to mycotoxins in food: Perspectives in a global and European context. Anal. Bioanal. Chem. 389: 147-157.

WHO (2009): Food Safety. Available at http://apps.who.int/gb/ebwha/pdf files/A62/A6 2 21-fr.pdf.

\section{مستويات الافلاتوكسين ما في الألبان وبعض منتجاتها في مدينة الإسكندرية \\ احد صلاح اللدين عياد ، حسين أبو المكارم \\ Email: ahmedaiad71@yahoo.com}

تعتبر الأفلاتوكسينات من السموم الفطرية عالية السمية والمسبية لكثير من الأمر اض السرطانية وهذة السموم الفطريـة تنتج كنو اتج ثانويـة أثناء

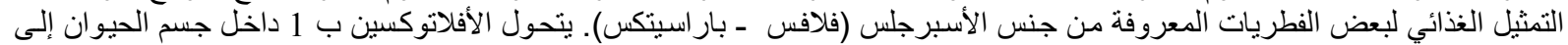

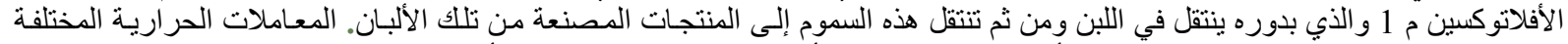

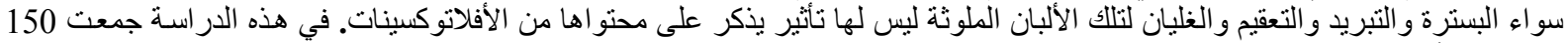

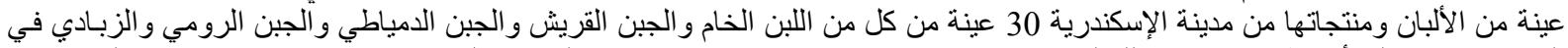

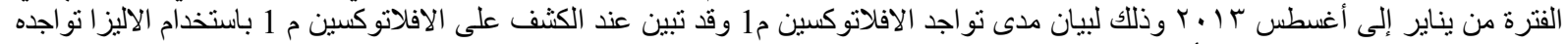

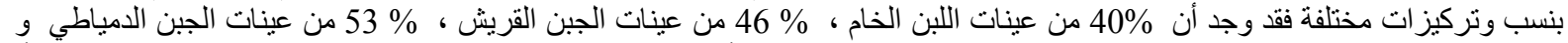

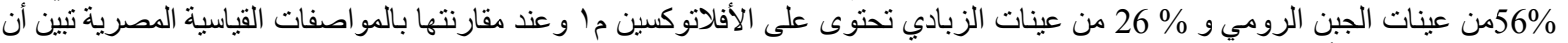

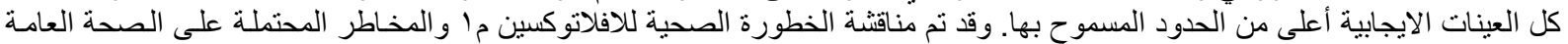
وخاصة صحة الأطفال. 